\title{
A comparison of the milk yield and morphometrics of Irtysh type Simmental cows and their Holstein and Simmental crosses in East Kazakhstan
}

\author{
AMANZHAN MAKSUTKANOVICH NUSUPOV ${ }^{1, \bullet}$, ADILKHAN ABUOVICH SAMBETBAEV ${ }^{1}$, \\ BOLATBEK ZHANAHMETOVICH KOZHEBAEV ${ }^{2}$, KULSARA HALIMARDENOVNA NURZHANOVA ${ }^{2}$, \\ OLGA VASILIEVNA GORELIK ${ }^{3}$ \\ ${ }^{1}$ Department of Technology of livestock production, Kazakh National Agrarian University. 8 Abai avenue, 050010, Almaty, Republic of Kazakhstan. \\ vemail: nest_01@myrambler.ru \\ ${ }^{2}$ Department of agriculture and bioresources, Shakarim University of Semey. 20-a, Glinka St, 071412, Semey, Republic of Kazakhstan \\ ${ }^{3}$ Ural State Agricultural University. 42, Karl Liebknecht St, 620075, Yekaterinburg, Russian Federation
}

Manuscript received: 30 October 2020. Revision accepted: 12 August 2021.

\begin{abstract}
Nusupov AM, Sambetbaev AA, Kozhebaev BZ, Nurzhanova KH, Gorelik OV. 2021. A comparison of the milk yield and morphometrics of Irtysh type Simmental cows and their Holstein and Simmental crosses in East Kazakhstan. Biodiversitas 22: 36633670. Cattle breeding is still a significant part of agriculture manufacture both in milk and beef production. Dairy manufacture needs more and more modifications to increase milk productivity and produce milk with better nutrition properties. The authors present a comparison of the dairy cattle of the Simmental breed (Kazakhstan Irtysh type) and its cross-breeds with red-piebald Holstein and Simmental breeds. All the animals' breeds were studied in the time of the first lactation period in cows at the "Kamyshinskoye" farm, Shemonaikha District, East Kazakhstan region. When collecting the research results, we studied the milk productivity, exterior parameters, and reproductive indicators for the control animal group (Simmental breed Irtysh type) and the crosses (cross-breeds) of the red-piebald Holstein and Irtysh type and Simmental and Irtysh type. All data obtained in this study have been fully compared with the indicators of the first lactation period of Simmental cows of the Irtysh type. As a result of the study, authors have created the curve of the 305-day lactation period, studied the exterior of the animals, the morphological structures of the udder, and the annual capacity cycles of the tested cows' group. The milk yield obtained in the first complete lactation period from the red-piebald Holstein crossanimals was $240 \mathrm{~kg}$ or $4.2 \%$ more than the control mother group, but the average milk fat percentage has been $0.09 \%$ less. On the contrary, the cross of the Irtysh and Simmental breed has a yield less by $258 \mathrm{~kg}$ or $4.7 \%(5277 \mathrm{~kg})$, but a fat milk percentage has been $0.1 \%$ more.
\end{abstract}

Keywords: Cross-breed, dairy cattle, exterior, lactation productivity, udder measurement

\section{INTRODUCTION}

Dairy farming is one of the leading livestock industries in the world and Kazakhstan, in particular (Yessymkhanova et al. 2021). This industry solves the most pushing problem of mankind - the provision of food, primarily dairy and meat products (Nurgaliyeva et al. 2020). Asian countries dominate the milk production industry, supplying $40 \%$ of the total milk in the world (Oliveros 2019). The largest populations of dairy cattle, according to the data, are found in India- 297 million heads, Brazil- 214 million heads, and China- 141 million heads. The leaders in gross milk production of cows in the world are the USA and India (91.3 and 60.6 million tons, respectively) (Abylkasymov et al. 2014; Abramova et al. 2018; Trukhachev et al. 2018). Currently, dairy, milk, and meat cattle breeding are one of the main and intensively productive sectors of cattle breeding in the Kazakhstan republic. On the territory of the former Commonwealth of Independent States (CIS) countries, more than 30 dairy and milk-meat breeds are bred, including more than 10 dairy breeds in Kazakhstan. Among them, in the conditions of the eastern part of the country, there are many well-known livestock breeds, such as Simmental, Holstein, black pied, and red steppe cows (Nusupov and Akhmetova 2019; Simm et al. 2020; Cole et al. 2020). Simmental is one of the most common ancient breeds found in many European and Asian countries. The main homeland of this breed is Switzerland. In Kazakhstan, these breeds are widespread mainly in the northern, eastern, and central regions. These Simmental cattle are characterized by good meat production in the short term and high milk production during the lactation period. Due to such productivity indicators, these cattle are bred in large numbers on farms in the Shemonaikha, Ulan, Glubokoe, and Borodulikha districts of East Kazakhstan. These areas are known for providing all regions of the country with milk and dairy products (Palii et al. 2020; Nusupov et al. 2020a). Due to the demand for milk production in these farms, various technologies are exploited to further increase their production. One of them is the well-known method of cattle hybridization. This method originated in Kazakhstan in the distant 80s with an increase in the milk production of local Simmental cows and an improvement 
in the morphofunctional structures of the udders (Nusupov et al. 2020a). In modern conditions of East Kazakhstan, it resulted in appearance of three-breed Kazakhstani redpiebald dairy Simmental cows of the Irtysh type on large peasant farms, such as "Kamyshinskoye" and "E. Zaitenov". High physiological conditions and productive potential of these new Irtysh-type cows are reflected in their exterior indicators and indicators during development and their strong constitution (Rodionov et al. 2018; Anisimova 2019; Asylbekovich et al. 2019; Nusupov et al. 2020a). The average live weight of newborn calves of the Simmental cattle of the Irtysh type ranges from 38 to $41 \mathrm{~kg}$, and the live weight of an 18-month-old heifer is 420-460 $\mathrm{kg}$ (Nusupov et al. 2018; 2019). In terms of exterior indicators, these represent new groups of large cattle, high productivity, with a trough-like udder. During the lactation period, cows of the Simmental breed of the Irtysh type produce $6000-6500 \mathrm{~kg}$ of milk with an average of $4-4.2 \%$ fat content (Nusupov et al. 2018; 2019). Based on this, to further increase the milk productivity of cows of the Simmental breed of the Irtysh type and to prevent the loss of the breeding value of the livestock of Simmental breed on peasant farms in the conditions of the East Kazakhstan region, an improvement is carried out with the red-piebald Holstein and Simmental breeds. As a result, large highmilk yield crosses of red-piebald Holstein Irtysh $\mathrm{x}$ and Simmental Irtysh $\mathrm{x}$ appeared on the farm (Nusupov et al. 2020b).

\section{MATERIALS AND METHODS}

\section{The study of milk yield in hybrid cows}

We compared the milk productivity of Irtysh and Holstein cross-cows and Irtysh and Simmental cross-cows in the East Kazakhstan region during the first lactation period against the results of the Simmental-cows of the Irtysh type. So first of all, we had studied the average daily milk yield of the cross-cows of the first calving. In this aim, we combined the amount of milk milked in the morning and evening at the "Parallel" milking machine while participating in the monthly final control yield. During the final control yield, each cow was washed, and the first milk stream was milked from the cleaned udder. Then, evening and morning milk samples were combined in a special test tube of $100 \mathrm{~mL}$. We have determined the percentage of milk fat and protein content in it using an express machine "Lactan 1-4 M" in the laboratory "Research of milk" in the Semipalatinsk scientific and agricultural center. So, the quantity of final control yield per month was deduced based on the average daily milk yield, and the amount of milk produced per 305 days. This has determined the lactation period monthly curve (Samusenko and Mamaev 2010; Veissier et al. 2020).

\section{The determination of the exterior features of the first calving cross-cows}

This part of the study was conducted with the classifier's written permission and was determined in the second month of the lactation period by the basic zootechnical methods. Early in the morning (before feeding) on an even, clean and bright place, with a special device using (a Lidtin measuring stick) the height of the withers was measured (from the highest point of the withers to the ground); oblique length of the corpus (from the anterior bulge of the joint of the junction of the scapula and the humerus to the posterior bulge of the pelvic (ischium) bone); chest depth (from the highest point of the withers to the lowest point of the sternum outside the shoulder blade); chest width (from the outside of the scapula); the height of the coccygeal bone (from the highest point of the coccyx to the ground). Further measurements were taken with a measuring tape: chest girth-wrapped outside the scapula; metacarpus girth- from the thinnest part of the anterior lower leg (tibia), and with a measuring compass: intervertebral width- determined by measuring the distance between the farthest points of the ilium. Using all these body measurements, the body indices of the cross cows of the first calving were calculated using the following formulas (Samusenko and Mamaev 2010; Polyantsev 2014; Nusupov and Akhmetova 2019; Cole et al. 2020):

$$
\begin{aligned}
& \text { legginess }=\frac{\text { withers height }- \text { chest depth }}{\text { withers height }} \times 100 \% \\
& \text { nature of the body }=\frac{\text { oblique length of the body }}{\text { withers height }} \times 100 \% \\
& \text { chest }=\frac{\text { chest width }}{\text { chest depth }} \times 100 \% \\
& \text { chest - pelvis matching }=\frac{\text { chest width }}{\text { intervertebral width }} \times 100 \% \\
& \text { body blockiness }=\frac{\text { chest girth }}{\text { oblique length of the body }} \times 100 \% \\
& \text { body massiveness }=\frac{\text { chest girth }}{\text { withers height }} \times 100 \% \\
& \text { body width }=\frac{\text { coccyx heigh }}{\text { withers height }} \times 100 \% \\
& \text { boniness }=\frac{\text { metacarpus girth }}{\text { withers height }} \times 100 \%
\end{aligned}
$$

\section{The study of the udder exterior structure and milking parameters}

This part of our experiment was conducted using the Latvian method of visual inspection, a 25-point system. Cross-cows were tested in the second month of the lactation period. An udder has been measured by the measuring compass and measuring tape for such indices as udder girth, length, width, and depth. Moreover, measurements of the front and rear teats were taken into account, their length, diameter, and distance from each other (have been measured by a measuring tape). The udder index was calculated using the percentage of the total amount of produced milk to the amount of milk from the two front teats.

The milking rate was worked out by measuring the amount of milk that was milked for 1 minute during the 
final control yield (Asylbekovich et al. 2019; Rodionov et al. 2018; Trukhachev et al. 2018; Palii et al. 2020; Cole et al. 2020).

\section{The reproductive indexes detecting}

In order to determine the productivity indicators of the studied hybrid-cows, the measurements of 14-15-monthold physiologically mature heifers on electronic scales were taken. This allowed selected animals with live weights in the range of $360-380 \mathrm{~kg}$ to determine the weight and age of the first fertilization. Provided the age of the first calving cows in the study during their offspring, the average gestation duration was determined by the reduction in the period of first fertilization. The duration of the service period was obtained from the time of calving of the studied cross cows to the time of complete fertilization, while the inter-lactation period (dry period) was determined from the end of the lactation period to the time of repeated calving. The productivity coefficient was calculated using the percentage of days of calving of the crosses understudy to 365 days, while the percentage of fertilized crosses determined the fertilization index to all tested crosses (Polyantsev 2014; Anisimova 2019; Simm et al. 2020).

All study parameters in milk productivity, growth, and reproductive indices were calculated in the Excel computer program according to N.A. Plokhinsky.

\section{RESULTS AND DISCUSSION}

\section{The study of the milk productivity of the Simmental breed of Irtysh type and its crosses}

The Simmental breed is one of the most popular cattle breeds in the world. It is often using in cattle farming, and Kazakhstan is also in. Its milk productivity is well known in milk manufacture and allows to make dairy cattle farming economically viable (Mazur et al. 2020; Nusupov et al. 2020b). So, any breed enhancement must be tested in real results to be sure inputted changes were needed and made better this breed type. First of all, we have studied indicators of milk productivity in the East Kazakhstan region during the first-lactation period of the Irtysh type breed and its crosses with Holstein and Simmental breeds (Table 1). We have analyzed such indices as milk fat and protein as parameters of the milk nutrition in fact of the known data about depending on these parameters from the breed genetics (Polupan and Siriak 2019).

So, the cross of Simmental Irtysh type and red-piebald Holstein breed was more productive: $240 \mathrm{~kg}$ milk with an average fat content of $3.99 \%$, which was higher to $4.1 \%$ compared to Symental-Irtysh type (control). But cross-cow of Irtysh and Simmental breed was less productive in $4.7 \%$ compared to the control (258 kg of milk with an average fat content of $4.19 \%$ ). We can see that crossing in Simmental Irtysh type cows with red-piebald Holstein breed decreased the fat and protein in milk on average $0.09 \%$ and $0.02 \%$ due to an increase in milk yield. However, crossing the Simmental Irtysh type cows and Simmental cattle has increased the fat and protein content in milk by average of $0.11 \%$ and $0.04 \%$, respectively.

According to the data, if we take Simmental cows of the Irtysh type as control with $5535 \mathrm{~kg}$ of milk yield the mass fraction of fat and protein in $5775 \mathrm{~kg}$ of milk from the Irtysh and red-piebald Holstein crosses have been higher and averaged $4.6 \mathrm{~kg}$ or $2 \%$ and $6.7 \mathrm{~kg}$ or $3.6 \%$ more, respectively. It was noticed that the mass fractions of fat and protein in $5277 \mathrm{~kg}$ of milk of the cross for Irtysh and Simmental breed were $9.3 \mathrm{~kg}$ or $4.1 \%$ and $13.2 \mathrm{~kg}$ or $7 \%$ more liken the compared cross. So, it is the mass fractions of fat and protein in the milk of the Irtysh and Simmental crosses, and has proved to average $4.7 \mathrm{~kg}$ or $2.1 \%$ and 6.5 $\mathrm{kg}$ or $3.7 \%$ lower liken the control cows' group.

But we can not take the someone index like control because of its changing in different periods of lactation time (Trukhachev et al. 2018), so we had converted total milk yield in average milk mass. Figure 1 illustrates the results of converting the total amount of actual milk yield to milk with one percent content of basic fat in the lactation period, which helps us to equate the total milk of each group.

Converting into one percent milk $5535 \mathrm{~kg}$ of milk yield with an average fat percentage of $4.08 \%$ from the Simmental cows of the Irtysh type in the time of the first lactation period resulted in $22582.8 \mathrm{~kg}$, and the yield from its crosses of red-piebald Holstein and Irtysh type was $23042.3 \mathrm{~kg}$ (in $459.5 \mathrm{~kg}$, or $2 \%$ more), whilst the milk yield from Simmental and Irtysh breed cross has been in $\mathbf{4 7 2 . 2}$ $\mathrm{kg}$ lower. So, we see that milk converting into one percent milk is depended on the fat content and has changed milk yield: the control group has increased by $408 \%$, and its crosses in $399 \%$ and $418.9 \%$ respectively. Table 2 shows the percentage containing milk fat and protein monthly during the first lactation period (305 days).

The average daily milk yield of Simmental cows of the Irtysh type was $17.9 \mathrm{~kg}$ in 305 days, but it has been noted, in the first 100 days this amounted to $2178 \mathrm{~kg}$. And the average daily milk yield from cross-cows of Holstein redpiebald bred and Irtysh type was $18.7 \mathrm{~kg}$, and the Simmental breed and Irtysh type were $17.1 \mathrm{~kg}$. In the first 100 days, averagemilk yield of the tested cow-crosses was 2316 and $2133 \mathrm{~kg}$, correspondingly. thus, from the point of view of milk yields in the first 100 days, we can observe that red-piebald crosses in the first 100 days were on average $138 \mathrm{~kg}$ or $6 \%$ more than the Irtysh type cows, while the second cross-type, on the contrary, had the average $45 \mathrm{~kg}$ or $2.1 \%$ lower. Considering all these indicators, it should be noted that the average milk yield of the Irtysh type cows in the first 100 days amounted to $40.5 \%$ of the total milk yield in 305 days, while the yield of their crosses equaled $41.2 \%$ and $41.5 \%$, respectively. Figure 2 introduces a curve of the 305-day lactation period based on the final control monthly milk production results. 
Table 1. The milk indicators at the first lactation period of the Irtysh type breed and its crosses

\begin{tabular}{|c|c|c|c|c|c|c|}
\hline \multirow[t]{2}{*}{ Indicators } & \multicolumn{2}{|c|}{ Irtysh type cows, $n=15$} & \multicolumn{2}{|c|}{$\begin{array}{c}\text { Irtysh and red-piebald Holstein } \\
\text { crosses, } n=15\end{array}$} & \multicolumn{2}{|c|}{$\begin{array}{c}\text { Irtysh and Simmental } \\
\text { crosses, } n=15\end{array}$} \\
\hline & $\mathbf{X} \pm \mathbf{S}_{\mathbf{x}}$ & $\mathrm{C} v$ & $\mathbf{X} \pm \mathbf{S}_{\mathbf{X}}$ & $\mathrm{Cv}$ & $X \pm S_{x}$ & $\mathrm{Cv}$ \\
\hline Milk yield, kg & $5535 \pm 170.8$ & 11.95 & $5775 \pm 171.4$ & 11.49 & $5277 \pm 169.4$ & 12.43 \\
\hline Milk fat, $\%$ & $4.08 \pm 0.02$ & 2.15 & $3.99 \pm 0.03$ & 2.75 & $4.19 \pm 0.03$ & 2.97 \\
\hline Milk fat, $\mathrm{kg}$ & $225.8 \pm 2.15$ & 34.97 & $230.4 \pm 2.30$ & 36.73 & $221.1 \pm 2.15$ & 35.92 \\
\hline Milk protein, $\%$ & $3.31 \pm 0.04$ & 4.22 & $3.29 \pm 0.04$ & 4.46 & $3.35 \pm 0.04$ & 4.47 \\
\hline Milk protein, $\mathrm{kg}$ & $183.2 \pm 1.67$ & 33.74 & $189.9 \pm 1.82$ & 35.58 & $176.7 \pm 1.66$ & 3.86 \\
\hline
\end{tabular}

Table 2. Milk-quality marks of the Irtysh cattle-breed and its breed-crosses

\begin{tabular}{|c|c|c|c|c|c|c|c|c|c|}
\hline \multirow{2}{*}{$\begin{array}{l}\text { Yield } \\
\text { months }\end{array}$} & \multicolumn{3}{|c|}{$\begin{array}{c}\text { Irtysh type cows, } \\
n=15\end{array}$} & \multicolumn{3}{|c|}{$\begin{array}{c}\text { Crosses of the red-piebald Holstein } \\
\text { and Irtysh, } n=15\end{array}$} & \multicolumn{3}{|c|}{$\begin{array}{l}\text { Crosses of Simmental and Irtysh, } \\
n=15\end{array}$} \\
\hline & Milk, kg & Fat, \% & Protein, \% & Milk, kg & Fat, \% & Protein, \% & Milk, kg & Fat, \% & Protein, \% \\
\hline 1 month & 19.8 & 4.01 & 3.18 & 21.2 & 3.92 & 3.17 & 19.4 & 4.15 & 3.28 \\
\hline 2 month & 22.3 & 3.96 & 3.17 & 23.7 & 3.90 & 3.16 & 21.6 & 4.12 & 3.20 \\
\hline 3 month & 23.1 & 3.93 & 3.05 & 24.6 & 3.84 & 3.09 & 22.9 & 3.98 & 3.07 \\
\hline 4 month & 22.3 & 4.06 & 3.25 & 23.2 & 3.88 & 3.13 & 21.8 & 3.99 & 3.16 \\
\hline 5 month & 21.7 & 4.08 & 3.27 & 23.0 & 3.93 & 3.20 & 20.2 & 4.16 & 3.31 \\
\hline 6 month & 20.2 & 4.09 & 3.32 & 22.8 & 3.98 & 3.27 & 18.2 & 4.18 & 3.39 \\
\hline 7 month & 17.2 & 4.13 & 3.36 & 16.8 & 3.99 & 3.38 & 15.7 & 4.31 & 3.41 \\
\hline 8 month & 14.3 & 4.15 & 3.44 & 13.4 & 4.11 & 3.42 & 14.1 & 4.27 & 3.49 \\
\hline 9 month & 10.6 & 4.18 & 3.49 & 10.6 & 4.10 & 3.49 & 11.1 & 4.34 & 3.60 \\
\hline 10month & 8.0 & 4.21 & 3.50 & 7.7 & 4.16 & 3.47 & 6.9 & 4.33 & 3.56 \\
\hline Average & 17.9 & 4.08 & 3.30 & 18.7 & 3.98 & 3.27 & 17.1 & 4.18 & 3.34 \\
\hline
\end{tabular}

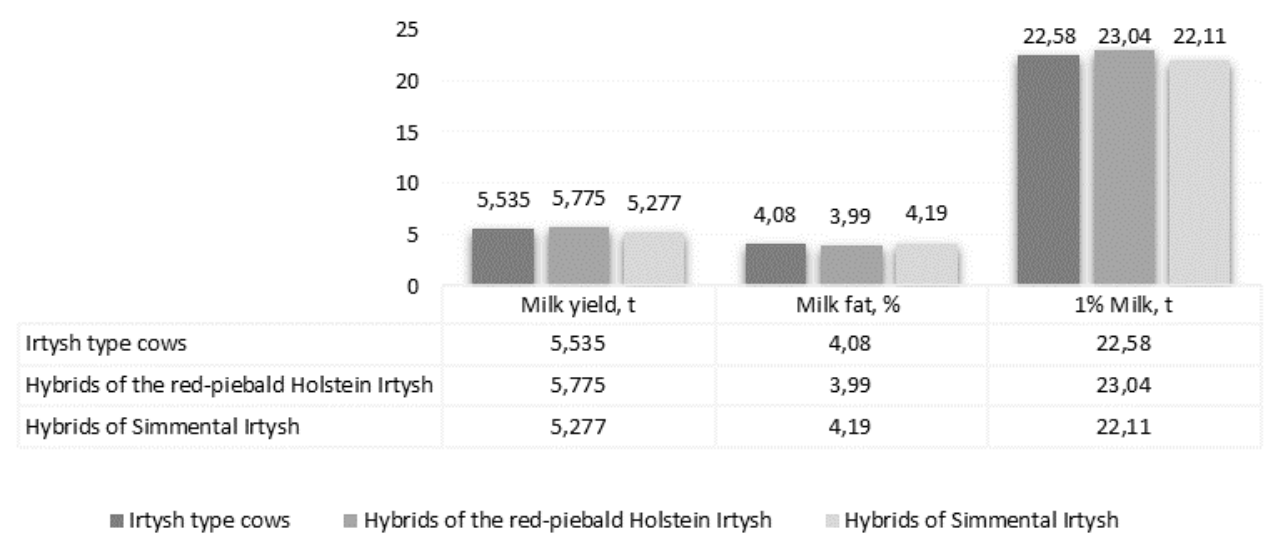

Figure 1. Changes in milk yield of cows of the Simmental breed of the Irtysh type and their crosses in the first lactation period due to the mass fraction of fat

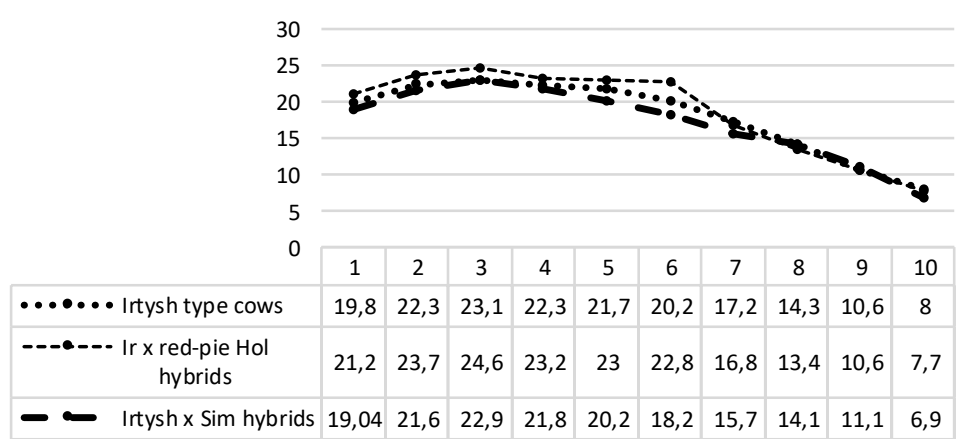

Figure 2. Curve of the 305-day lactation period 
So the curve of the lactation period of the Simmental cows of Irtysh type rose up from the first month of the lactation period to the third month and gradually decreases by the tenth milking month: this curve of this lactation period can be attributed to a uniform, single-peaked curve. It should be noted that the curve of the Irtysh and Simmental cross had no rapid decrease in the milk yield after the third milking month, it would also be as uniform and single-peaked as the curve of the Irtysh type cows. At the same time, the Holstein red-piebald and Irtysh cross had the curve rising from the first milking month to the third milking month, has decreased from the fourth to sixth milking month, and only after that decreases: this curve can be attributed to a single-peaked and long-term.

According to the results of the milk yield in the 305-day lactation period, the Irtysh and Simmental cross had rather small even if compared with the milk yield from the single Irtysh cows-type. But the red-piebald Holstein and Irtysh cross-type had better results in general milk mass.

\section{The exterior indicators of the studied cows breed types}

Cows' exterior is an important indicator to organize farm manufacture (Rodionov et al. 2018). We have taken care of live weight and body properties to make balanced herd (Samusenko and Mamaev 2010). So, the next point of our research was to test exterior indicators of the presented crosses and control breed type. Table 3 presents the results of body measurements in the second month of the first lactation period.

All studies aimed to obtain exterior indicators were conducted in accordance with zootechnical requirements in the second month of the lactation period. So, we have tested body measurements, the average height of the withers and coccygeal bone, which shows the growth, and to the Simmental cows of the Irtysh type these parameters were $135.2 \mathrm{~cm}$ and $141.3 \mathrm{~cm}$; for the red-piebald Holstein cross there was an average of $0.7 \mathrm{~cm}$ and $1.2 \mathrm{~cm}$ less, and to the Simmental cross, on the contrary, were got higher an average of $1 \mathrm{~cm}$ and $1.6 \mathrm{~cm}$. In terms of the width and depth of the chest size, the red-piebald crosses demonstrated $1.3 \mathrm{~cm}$ and $2 \mathrm{~cm}$ lower parameters compare to the Irtysh type cows, but the Simmental cross-type had measurements by $1.4 \mathrm{~cm}$ and $2.3 \mathrm{~cm}$ higher.

So, the Holstein dairy cattle cross-type has decreased in terms of body measurements compared to the control Simmental Irtysh type, but on the other hand, the Simmental cross-type peers have increased in all body measurements and turned to the initial level of Simmental cattle.

\section{The udder accordance study}

Udder exterior is an important parameter for dairy farming because of its influence on machine-taking milk yield (Rodionov et al. 2018; Bujko et al. 2018). Another manufacture important index for milk-production industry is udder measurements. Table 4 presents the results of body measurements that were carried out in accordance with zootechnical standards in the second month of the lactation period.
The measurement results showed that Holstein-crosses had the biggest udders in terms of length, width, girth, and depth. The second cross-group (Simmentalised cows) had much smaller udder indexes measurements. And the teats indexes were different: the length of the front teats in redpiebald cross-cows increased on average by $0.1 \mathrm{~cm}$ compared to mothers' animals, and the diameter decreased by $0.1 \mathrm{~cm}$. The teatlength of the Simmental cross-cows has been decreased by $0.1 \mathrm{~cm}$ but their diameter remains the same. The distance from the bottom of the udder to the ground for the Irtysh type cows averaged $58.3 \mathrm{~cm}$, while for its red-piebald Holstein cross-breeds it decreased by an average of $0.3 \mathrm{~cm}$, and for Simmental cross-breed, contrary, has increased by $0.6 \mathrm{~cm}$. For all the obtained results determined in the final control in the second lactation period, red-piebald Holstein cross-cows had udder indicesmore by $0.3 \%$ compared to the Irtysh type cows, whereas cross of the Simmental breed was $0.4 \%$ lower.

As for the rate of the yield-time, it is worth being noted, the Holstein red-piebald cross-cows produced milk 0.07 $\mathrm{kg} / \mathrm{min}$ faster than their mothers, while Simmentalised cross-cows were by $0.07 \mathrm{~kg} / \mathrm{min}$ slower.

\section{The study of the reproductive possibilities of the tested cows' group}

We evaluated reproductive productivity indicators for the control animal group and their crosses as an indicator of the herd reproduction speed (Table 5).

So, the age of the first fertilization and the live weight of the red-piebald crosses of the Holsteinised breed decreased on average by 12 days and $16 \mathrm{~kg}$, or $4.2 \%$, compared with the Irtysh Simmental cows, while this indicator decreased in Simmentalisated cross on average by 36 days and $10 \mathrm{~kg}$ or $2.8 \%$. Due to this, the age of the first offspring can be reduced on average from 13 to 35 days, depending on the characteristics of the cows' gestation period. Suppose the decrease in the productivity coefficient of cows of the Simmental breed of the Irtysh type compared to crosses of the red-piebald Holstein breeds by $0.01 \%$ can be explained by an increase in the lactation period and the service period. In that case, an increase of this indicator by $0.01 \%$ in crosses of the Simmental breed can be explained by a decrease in the lactation period and service period. As for the Fecundation index, \%, the crosses showed an average of $0.06 \%$ lower index than cows of the Simmental breed of Irtysh type. The index is close to one, and it is a good indicator, which confirms that the crosses are more fertile than their mothers. Indicators of the annual cycle capacity of cows taken in this study can be observed in Figure 3.

Results of the first lactation period show the duration of the complete lactation period in Irtysh cows averaged 325 days, while the dry period was on average 52 days and their annual capacity cycle was on average 377 days. The dry period of the red-piebald Holstein cross has been decreased by an average of 2 days or $3.9 \%$ due to the elongation of the lactation period an average of 7 days or $2.2 \%$. The lactation period of the Irtysh and Simmental cross-cows has 
been decreased the average by 9 days or $2.8 \%$, and the dry period was elongated by an average of 6 days or $10.4 \%$.

The average annual capacity cycle of the Simmental cows of the Irtysh type concludes 284 days of gestation period and 90 service period days. These indexes for the cross of red-piebald Holstein and Irtysh type breed were some different: the gestational period has been decreased by a day, and the service period was increased by 6 days. For the animals of the Simmentalised cross, the gestational period was increased by a day, and the service period has been decreased by 4 days.

Table 3. Exterior indicators of Simmental cows of the Irtysh type and their crosses

\begin{tabular}{|c|c|c|c|c|c|c|}
\hline \multirow{2}{*}{ Body measurements, cm } & \multicolumn{2}{|c|}{ Irtysh type cows, $n=15$} & \multicolumn{2}{|c|}{$\begin{array}{c}\text { Irtysh and red-piebald } \\
\text { Holstein cross, } n=15\end{array}$} & \multicolumn{2}{|c|}{$\begin{array}{l}\text { Irtysh and Simmental cross, } \\
n=15\end{array}$} \\
\hline & $\mathbf{X} \pm \mathbf{S}_{\mathbf{x}}$ & $\mathrm{Cv}$ & $\mathbf{X} \pm \mathbf{S}_{\mathbf{x}}$ & $\mathrm{Cv}$ & $\mathbf{X} \pm \mathbf{S}_{\mathbf{x}}$ & $\mathrm{Cv}$ \\
\hline Withers height & $135.2 \pm 0.40$ & 1.15 & $134.5 \pm 0.48$ & 1.40 & $136.5 \pm 0.47$ & 1.34 \\
\hline Coccyx height & $141.3 \pm 0.41$ & 1.13 & $140.1 \pm 0.47$ & 1.32 & $142.9 \pm 0.45$ & 1.22 \\
\hline Oblique length of the body & $170.2 \pm 0.41$ & 0.95 & $170.0 \pm 0.43$ & 0.98 & $171.3 \pm 0.36$ & 0.82 \\
\hline Chest girth & $196.1 \pm 0.48$ & 0.95 & $194.3 \pm 0.41$ & 0.82 & $199.7 \pm 0.45$ & 0.87 \\
\hline Chest depth & $76.3 \pm 0.41$ & 2.10 & $74.3 \pm 0.41$ & 2.15 & $78.6 \pm 0.42$ & 2.11 \\
\hline Chest width & $46.4 \pm 0.43$ & 3.61 & $45.1 \pm 0.48$ & 4.15 & $47.8 \pm 0.31$ & 2.58 \\
\hline Intervertebral width & $52.4 \pm 0.31$ & 2.29 & $51.8 \pm 0.33$ & 2.52 & $53.8 \pm 0.49$ & 3.53 \\
\hline Metacarpus girth & $19.7 \pm 0.06$ & 1.24 & $19.3 \pm 0.05$ & 1.11 & $20.9 \pm 0.09$ & 1.81 \\
\hline
\end{tabular}

Table 4. Udder measurements and indicators of the Simmental cows of the Irtysh type and its crosses

\begin{tabular}{|c|c|c|c|c|c|c|c|}
\hline \multicolumn{2}{|c|}{ Measurements } & \multicolumn{2}{|c|}{ Irtysh type cows, $n=15$} & \multicolumn{2}{|c|}{$\begin{array}{l}\text { Irtysh } \times \text { red-piebald } \\
\text { Holstein crosses, } n=15\end{array}$} & \multicolumn{2}{|c|}{$\begin{array}{l}\text { Irtysh x Simmental } \\
\text { crosses, } n=15\end{array}$} \\
\hline & & $\mathbf{X} \pm \mathbf{S}_{\mathbf{x}}$ & $\mathrm{Cv}$ & $\mathbf{X} \pm \mathbf{S}_{\mathbf{x}}$ & $\mathrm{Cv}$ & $\mathbf{X} \pm \mathbf{S}_{\mathbf{x}}$ & $\mathrm{Cv}$ \\
\hline \multirow[t]{4}{*}{ Udder } & Length & $40 \pm 0.34$ & 3.35 & $41.2 \pm 0.38$ & 3.63 & $39.6 \pm 0.33$ & 3.28 \\
\hline & Width & $33 \pm 0.27$ & 3.27 & $33.5 \pm 0.30$ & 3.47 & $32.8 \pm 0.27$ & 3.25 \\
\hline & Girth & $125 \pm 1.00$ & 3.12 & $127.1 \pm 1.01$ & 3.08 & $124.6 \pm 0.73$ & 2.27 \\
\hline & Depth & $28 \pm 0.32$ & 4.47 & $29 \pm 0.32$ & 4.26 & $27 \pm 0.37$ & 5.29 \\
\hline \multirow{2}{*}{ Front teats } & Length & $7 \pm 0.18$ & 10.29 & $7.1 \pm 0.14$ & 7.79 & $6.9 \pm 0.12$ & 7.05 \\
\hline & Diameter & $2.7 \pm 0.03$ & 4.87 & $2.6 \pm 0.04$ & 7.02 & $2.7 \pm 0.02$ & 4.07 \\
\hline \multirow{2}{*}{ Rear teats } & Length & $6.4 \pm 0.07$ & 4.73 & $6.6 \pm 0.07$ & 4.17 & $6.4 \pm 0.02$ & 1.46 \\
\hline & Diameter & $2.8 \pm 0.02$ & 2.91 & $2.6 \pm 0.01$ & 2.96 & $2.7 \pm 0.02$ & 4.22 \\
\hline \multirow[t]{3}{*}{ Distance between teats } & Front & $13 \pm 0.25-$ & 7.42 & $13.3 \pm 0.29$ & 8.58 & $13 \pm 0.24$ & 7.31 \\
\hline & Rear & $10 \pm 0.08$ & 3.21 & $10.1 \pm 0.09$ & 3.51 & $9.8 \pm 0.11$ & 4.48 \\
\hline & Front and rear & $8.7 \pm 0.07$ & 3.41 & $8.8 \pm 0.10$ & 4.44 & $8.7 \pm 0.05$ & 2.35 \\
\hline \multicolumn{2}{|c|}{$\begin{array}{l}\text { Distance from the bottom of the udder to } \\
\text { the ground }\end{array}$} & $58.3 \pm 0.57$ & 3.84 & $58 \pm 0.57$ & 3.80 & $58.9 \pm 0.50$ & 3.29 \\
\hline \multicolumn{2}{|c|}{ Udder index, $\%$} & \multicolumn{2}{|c|}{46.8} & \multicolumn{2}{|c|}{47.1} & \multicolumn{2}{|c|}{46.4} \\
\hline \multicolumn{2}{|c|}{ Speed of milk yield, $\mathrm{kg} / \mathrm{min}$} & \multicolumn{2}{|c|}{1.85} & \multicolumn{2}{|c|}{1.92} & \multicolumn{2}{|c|}{1.78} \\
\hline
\end{tabular}

Table 5. Reproductivity indices of the Simmental cows of the Irtysh type and their crosses

\begin{tabular}{|c|c|c|c|c|c|c|}
\hline \multirow[t]{2}{*}{ Indicators } & \multicolumn{2}{|c|}{ Irtysh type cows } & \multicolumn{2}{|c|}{$\begin{array}{l}\text { Irtysh x red-piebald } \\
\text { Holstein crosses }\end{array}$} & \multicolumn{2}{|c|}{ Irtysh x Simmental crosse } \\
\hline & $\mathbf{X} \pm \mathbf{S}_{\mathbf{X}}$ & $\mathrm{Cv}$ & $\mathbf{X} \pm \mathbf{S}_{\mathbf{X}}$ & $\mathrm{Cv}$ & $\mathbf{X} \pm \mathbf{S}_{\mathbf{X}}$ & $\mathrm{C} v$ \\
\hline Age of first fertilization, days & $447 \pm 1.27$ & 1.10 & $435 \pm 1.20$ & 1.06 & $411 \pm 1.38$ & 1.30 \\
\hline Weight of the first fertilization, $\mathrm{kg}$ & $382 \pm 1.75$ & 1.77 & $366 \pm 2.18$ & 2.31 & $372 \pm 1.85$ & 1.92 \\
\hline Age of first calving, days & $730 \pm 1.71$ & 0.91 & $717 \pm 1.69$ & 0.91 & $695 \pm 1.87$ & 1.04 \\
\hline Gestation period, days & $283 \pm 0.56$ & 0.77 & $282 \pm 0.53$ & 0.73 & $284 \pm 0.53$ & 0.72 \\
\hline Duration of the lactation period, days & $325 \pm 1.13$ & 1.35 & $332 \pm 1.78$ & 2.08 & $316 \pm 1.39$ & 1.70 \\
\hline Service period, days & $94 \pm 1.36$ & 5.80 & $100 \pm 1.89$ & 7.32 & $90 \pm 1.65$ & 7.09 \\
\hline Inter-lactation period, days & $52 \pm 0.64$ & 4.83 & $50 \pm 0.78$ & 6.03 & $58 \pm 0.75$ & 5.03 \\
\hline Calving interval, days & $377 \pm 1.66$ & 1.71 & $382 \pm 2.37$ & 2.40 & $374 \pm 2.07$ & 2.14 \\
\hline Productivity ratio, $\%$ & \multicolumn{2}{|c|}{0.96} & \multicolumn{2}{|c|}{0.95} & \multicolumn{2}{|c|}{0.97} \\
\hline Fecundation index, $\%$ & \multicolumn{2}{|c|}{1.17} & \multicolumn{2}{|c|}{1.11} & \multicolumn{2}{|c|}{1.11} \\
\hline
\end{tabular}




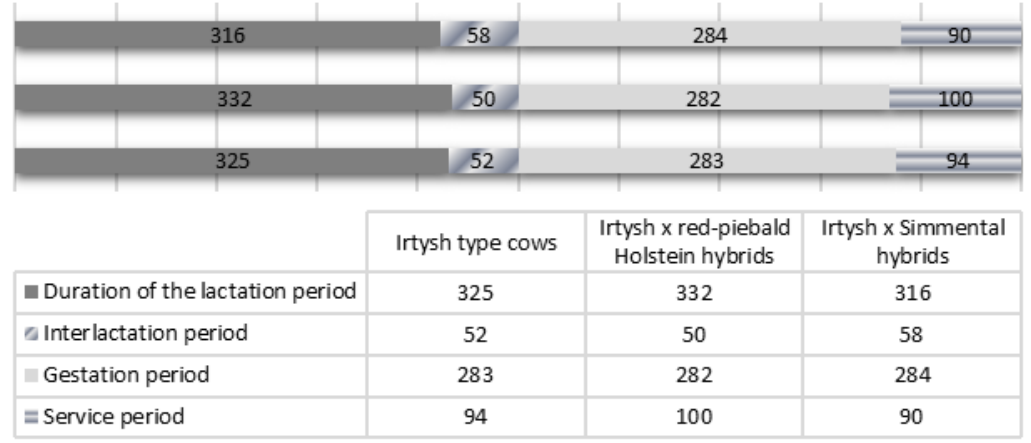

Figure 3. The annual cycle of the capacity of Simmental cows of the Irtysh type and their crosses

In central European and eastern European countries, the Simmental breed is more often used in different programs of cross-breeding with other fattening breeds in the case when it is grown in the cow-calf system. Thus Perišić et al. (2009) in eastern Germany studied the effects of outdoor rearing on 221 herds of pure, bred nursing cows and crossbreds of Galloway, Montafon, Limousine, German Red, German Angus, Aberdeen-Angus, Charolais and Simmental nursing cows on reproductive results and production of young bulls. The animals were held outside in $40 \%$ of herds during winter. Number of young bulls weaned per cow ranged from 0.87 for rougher breeds to 0.91 for large breeds (Charolais and Simmental), but there were not significant differences between breeds in the weight of young bulls produced at $100 \mathrm{~kg}$ of cow body mass. The cost of feeding was $15 \%$ higher for the cows that spent the winter outside to keep cows stable. It was concluded that, under the dominant conditions in Germany, the outdoor rearing of cattle of small breeds has certain advantages.

General prerequisites for the success and economics of meat production in the cow-calf system, besides pronounced fattening qualities of Simmental breed, are also regular fertility and the existence of the conditions for fattening with smallest possible feeding cost (use of pastures, green fodder). In order to achieve the maximal possible fertility, the induction and oestrus synchronization should be Simmental cattle breed in different production systems 323regularly applied. In this way, the shortening of the duration of the service period could be influenced upon, and increase the $\%$ of twinning by a controlled increased dose of applied hormone (per type FSH), which is of great importance in this production. The calvings should be planned in accordance with real climate conditions in a given region to utilize maximally the vegetation period (pasture) by cows and calves.

Tschumperlin et al. (2001) compared the productive efficiency of dual-purpose medium-sized Simmental cows and Aberdeen-Angus cows. A whole herd was mated with Angus bulls. The young Simmental x Aberdeen-Angus bulls had a higher live weight gain in live body weight and net mass in relation to purebred Angus young bulls. In addition, Simental x Angus young bulls had a higher yield of meat and better meat quality in relation to Angus young bulls (difference of $0.6 \%$ and $1.0 \%$ ). A superiority of dualpurpose type of cows in relation to a specialized fattening type in this system of meat production is caused mostly by a higher milk yield in Simmental cows.

The importance of Simmental breed, besides its good results at crossbreeding with other cattle breeds, is also seen cross-breeding with Zebu cattle, in which process it transfers its good traits into the crosses. In this way, classic industrial cross-breeding to obtain F1 hybrid of Simmental breed and Zebu cattle is performed, and a great number of fattening breeds are created on the basis of cross-breeding of Simmental breed and Zebu. Thanks to good adaptability, Simmental breed has spread from Europe to all continents and different climate regions, where it is mostly reared in the system cow-calf, in pure breed or is being crossed with fattening breeds of cattle or Zebu breeds. Thus, in the African continent Simmental breed is mostly used for cross-breeding with local Zebu breeds (Grupp 1994), and it is important to say that for tropical regions Simmental cattle with curly hair is not appropriate what should be given attention to when making the choice of the bull semen or bulls themselves.

In conclusion, the milk yield obtained in the first complete lactation period from the red-piebald Holstein cross-animals was $240 \mathrm{~kg}$ or $4.2 \%$ more compare control mother-group, but the average milk fat percentage has been of $0.09 \%$ less. The cross of the Irtysh and Simmental breed has a yield less by $258 \mathrm{~kg}$ or $4.7 \%(5277 \mathrm{~kg})$, but a fat milk percentage has been $0.1 \%$ more. The lactation period curve reflecting the average daily milk yield in each month was single-peaked and uniform for the Irtysh type cows and their Simmental cross, while a single-peaked continuous curve has been found in the Irtysh red-piebald Holstein cross.

On the basis of the stated research results obtained by domestic and foreign authors when studying the productive traits in Simmental breed in different rearing systems, remarkably lower milk production in Simmental breed in our country is perceived in relation to an average production realized by the animals of Simmental breed in majority of European countries. Such a state in production points to a more intensive improving work for the purpose of improving the milk yield traits in Simmental breed. An applied method of improvement in some populations 
should be reconciled with the already existing genetic potential of each actual population, its purpose (registered breeding stock, productive breeding stock), and the market needs for cow milk and dairy products.

The legginess index for the red-piebald Holstein Irtysh type cross was $1.2 \%$ higher compare to the Irtysh type of the Simmental cows, and $2.3 \%$ more than the Simmentalcross peers. The Holstein cross-type had shown the increase in milk yield indicators but the indices of blockiness and body width, alongside the meatiness indices, have been decreased. Whereas the Irtysh and Simmental cross has shown an increase in meatiness and was by $0.8 \%$ more compared to the boniness index to the Irtysh type cows, and are $1 \%$ more than their red-piebald peers.

The udder measurements and the amount of milk yield of the red-piebald Holstein crosses increased on average by $0.3 \%$ compared with the Irtysh cows, unlike among their Simmentalised peers, which had decreased parameters by $0.4 \%$. The milk yield rate respectively increased and decreased in the range of $\pm 0.07 \mathrm{~kg} / \mathrm{min}$.

The average annual capacity cycle of Simmental cows of the Irtysh type was 377 days. And its red-piebald cross of the Holstein breed was increased by 5 days or $1.4 \%$, while the crosses of the Simmental breed were decreased by 3 days or $0.8 \%$.

So, the Irtysh red-piebald hybrid cows in the conditions of the eastern Kazakhstan region had higher milk productivity and a decrease in live weight. Simmentalised cows (the Irtysh and Simmental hybrid) due to the fact that their body measurements were closer to the dairy cattle like their mothers-animals, but had an increase in the body measurement and live weight. Their milk productivity has been decreased, which shows the identification of the properties of Simmental cattle.

\section{REFERENCES}

Abylkasymov D, Ionova LN, Sudarevm. 2014. Milk Productivity and Indicators of the Reproductive Ability of Cows, Depending on Individual Factors. Dairy and Beef Cattle Breeding, Moscow. [Russian]

Abramova NI, Khromova OL, Vlasova GS, Bogoradova LN. 2018. The state of dairy cattle breeding in the world, in Russia and Vologda oblast. Agrozootehnika 1 (2): 1-11. DOI: 10.15838/alt.2018.2.2.1.

Anisimova EI. 2019. Immunogenetic parameters in the breeding of Simmental cattle. Agricultural Science of the Euro-North-East 20 (4): 398-406. DOI: 10.30766/2072-9081.2019.20.4.398-406 [Russian]

Asylbekovich BD, Kurmanbaiuly AS, Beskempirovich SN, Erbosynovich CA, Kurmanbaevich DE, Seydakhanuly ZB, Bakytkyzy M S. 2019. Productivity and estimated breeding value of the dairy cattle gene pool in the Republic of Kazakhstan. Bul NAN RK (2): 14-27. DOI: 10.32014/2019.2518-1467.36. [Russian].

Bujko J, Candrák J, Strapák P, Žitný J, Hrnčár C. 2018. The impact of genetic and non-genetic factors on somatic cell count as a monitor of udder health in Slovak Simmental dairy cows. Acta Fytotechn Zootechn 21 (4): 166-168. DOI: 10.15414/afz.2018.21.04.166-168.

Cole JB, Eaglen SA, Maltecca C, Mulder HA, Pryce JE. 2020. The future of phenomics in dairy cattle breeding. Anim Frontiers 10 (2): 3744.DOI: $10.1093 / \mathrm{af} / \mathrm{vfaa} 007$
Gruup T. 1994. The changing history of the breeding of German Simmental cattle in Namibia. Tierzuchter 46: 34-37.

Mazur NP, Fedorovych VV, Fedorovych EI et al. 2020 Effect of morphological and biochemical blood composition on milk yield in Simmental breed cows of different production types. Ukr J Ecol 10 (2): 61-67 . DOI: 10.15421/2020_110.

Nurgaliyeva A, Titkov A, Dontsov S, Karimbergenova M, Bayandina G. 2020. Improving economic methods of agricultural development in the Republic of Kazakhstan. REPORTS 1(329): 88-95. DOI: 10.32014/2020.2518-1483.11.

Nusupov AM, Sambetbaev AA, Kozhebaev BZ, Ponomoreva LA. 2018. Growth and development of calf cows of first-calf Simmental crosses of the Irtysh type. Bulletin of Semey State University named after Shakarim, Kazakhstan.

Nusupov AM, Akhmetova BS. 2019. Textbook on the Basics of Cattle Breeding. Shakherim Semey University, Semey, Kazakhstan.

Nusupov AM, Sambetbaev AA, Kozhebaev BZ. 2019. Indicators of live weight of dairy crosses of Simmental calves of the Irtysh type. Materials of the international scientific conference "Current state, development, prospects and modernization of the agro-industrial complex of the Republic of Kazakhstan". Semey State University named after Shakarim, Kazakhstan.

Nusupov AM, Sambetbaev AA, Kozhebaev BZ. 2020a. Morphofunctional structures of the udder of the Simmental cows. Collection of the International scientific-practical conference of young scientists in the framework of the Summer International School, Kaz NAU, Almaty, Kazakhstan.

Nusupov AM, Sambetbaev AA, Kozhebaev BZ, Ponomoreva LA. 2020 b. Exterior characteristics of Simmental cows during the first lactation period. Bulletin of Semey State University named after Shakarim 2 (123): 87-91.

Oliveros MCR. 2019. The Dairy Industry in Southeast Asia: Perspective, Challenges and Opportunities. IOP Conf Ser Earth Environ Sci 372: 1-9. DOI:10.1088/1755-1315/372/1/012068.

Palii AP, Nanka OV, Naumenko OA, Prudnikov VG, Paliy AP. 2019. Preconditions for eco-friendly milk production on the modern dairy complexes. Ukr J Ecol 9 (1):56-62.

Perišić P, Skalicki Z, Petrović MM, Bogdanović V, Ružić-Muslić D. 2009. Simmental cattle breed in different production systems. Biotechnol Anim Husbandry 25 (5-6-1): 315-326. DOI: 10.2298/BAH0906315P.

Polyantsev NI. 2014. Breeding Technology. Lan'. St. Petersburg. [Russian]

Polupan YP, Siriak VA. 2019. Influence of the intensively of formation on live weight of heifers and milk productivity of cows. J Anim Breed Genet 57: 111-125. DOI: 10.31073/abg.57.14.

Samusenko LD, Mamaev AV. 2010. Practical Lesson on Cattle Breeding. Lan'. St. Petersburg. [Russian]

Rodionov GV, Tabakova LP, Ostroukhova VI. 2018. Private Animal Husbandry and Livestock Production Technology. Lan'. St. Petersburg. [Russian]

Simm G, Pollott G, Mrode R, Houston R, Marshall K. 2021. Dairy cattle breeding. Genet Improv Farm Anim 2021: 234-291. DOI: 10.1079/9781789241723.0234.

Tschumperlin K, Erdin D, Leuenberger H, Kunzi N. 2001. Production parameters in a suckler cow system with Simmental and Angus cows on alpine pastures. Agrarforschung 8 (4): 168-173.

Trukhachev VI, Kapustin IV, Zlydnev NZ, Kapustina EI. 2018. Milk: State and Problems of Production. Lan'. St. Petersburg. [Russian]

Veissier I, Wagner N, Mialon MM, Lardy R, Ledoux D, Silberberg M, Meunier B. 2020. Potential benefits and risks of using Precision Livestock Farming technologies to manage animal welfare-Recent developments at INRAE. Precision Livestock Farming Workshop, United Kingdom.

Yessymkhanova Z, Niyazbekova S, Tochieva L, Goigova M, Varsin V, Varaksa N, Zubets A. 2021. Livestock products of households in ensuring food security in Kazakhstan. E3S Web of Conferences 284: 1-7. DOI: $10.1051 / \mathrm{e} 3$ sconf/202128402020. 